\title{
A Document on the Economic Status of the Lutsk Karaites in the Mid-19 ${ }^{\text {th }}$ century
}

\section{Anna Sulimowicz}

University of Warsaw

\begin{abstract}
Among the various documents preserved in the community's archives is a handwritten list containing the names, properties and professions of the Lutsk Karaites. Compiled in 1854, it provides data about various economic and social aspects of the community's life in the mid-19 $9^{\text {th }}$ century. It is also a valuable source of information on anthroponomy and genealogy. In the article, the content of the manuscript is presented, as well as additional information obtained through a comparison with other sources.
\end{abstract}

\section{Keywords}

Karaites, Karaite demography, Lutsk Karaite community, Karaite manuscripts, Karaite archives

\section{Introductory remarks}

The social and economic conditions of the Lutsk Karaite community, as well as its financial status and sources of livelihood of its members, remain for the most part unknown. Ananiasz Zajaczkowski claims that the Karaites settled in Lutsk as an "element rolniczy" (agricultural element) (ZAJĄCZKowski 1933, 24). Indeed, such names as "pola karaimowskie" (Karaite fields) or "dworzyszcza karaimowskie" (Karaite farmsteads) are found in documents dating back to the $16^{\text {th }}-18^{\text {th }}$ centuries (GĄSIOROWSKI 2008, 193; ZAJĄCZKOWSKI 1933, 24-28); however, there is no evidence that the Karaites of Lutsk were farmers. In a petition addressed by the community sometime between June 22, 1792 and May 1792 (W 'Trkowski 2007) to a commission of the Great Sejm, it is stated 
that "grunta siejemy i obrabiamy" (we sow and till the land), but at the same time it is emphasized that they worked the land only in Halicz and Kukizów (Materiały 1969, 525). This clearly shows that the Karaites in Lutsk, unlike those living in the two places mentioned, were not farmers, though they might have owned or leased land.

At the end of the $16^{\text {th }}$ century, a certain Karaite from Lutsk named Moszko Batkowicz leased a tavern, a mill and road tolls in the village of Błudów in the vicinity of Lutsk (GASIOROWSKI 2008, 357). He and his compatriot, Danko Igudycz also loaned money to local noblemen, and had problems obtaining repayment for those loans. Later in the next century, many Lutsk Karaites were involved in this kind of financial activity, among them Nisan, Abram Szmujłowicz, Nachum, Szmojło Abramowicz, Jusko, Icek Abramowicz (GĄSIOROwSKI 2008, 359). In a report from 1765, we find Karaites as the lessees of taverns in three villages near Lutsk (GASIOROWSKI 2008, 361). From a complaint by Christian tailors, we learn that in the $16^{\text {th }}$ century they had Karaite competitors (GAsIOROWSKI 2008, 360). Zelman the Tailor and Horszek the Shoemaker are mentioned among the owners of houses on Karaimska Street in Lutsk in the Lustracja for the year 1789. However, contrary to what Gąsiorowski claims (GĄSIOROWSKI 2008, 361), these are most probably not Karaites, judging by their names, but Rabbanite Jews. Another document from the community's archive, namely a certificate issued in the name of a certain Samuel Ickowicz by the Crown Treasury Commission, reveals that towards the end of the $18^{\text {th }}$ century there was at least one Karaite butcher in Lutsk. ${ }^{1}$

Moreover, Aleksander Kozieradzki (1813-1860), a Polish physician, spent a few years of his childhood in Lutsk, where he attended grade school, and has left an interesting note in his memoirs on the local Karaites in the 1820s: "Lutsk had and still has a characteristic peculiar to this town [...] that is the Karaite population settled here in the times of Witold. [...] Carting, butchery, selling dairy products were ways they made their living. Some families moved to nearby villages and engaged themselves in farming or managing taverns" (KozIERADZKI, 1962, 51).

The documents from community's archives can shed much light on the economic aspect of the lives of the Lutsk Karaites. In the sixth volume of Karaj Awazy, its editor, Aleksander Mardkowicz published an article (MarDKowicz

\footnotetext{
${ }^{1}$ Archives of the Karaite Community in Lutsk (AGKŁ), catalogue No. VII/24/II/O2.
} 
1933) on old handwritten documents stored in the gallery for women in the Karaite prayer house in Lutsk, complementing it with a transcription of seven letters found there. The manuscripts discovered by Mardkowicz fortunately remained intact during World War Two and were safely brought to Poland when on July 15, 1945 the members of the Lutsk Karaite community left their hometown to move westwards to the so-called "Recovered Territories" (Dubińska 1999). The collection contains not only letters, ${ }^{2}$ but various documents from the $18^{\text {th }}-19^{\text {th }}$ centuries, concerning mainly administrative matters. Among them is a document which received the catalogue number 4/79. It is a table containing a list of names of Karaites and information on their properties and sources of livelihood. In the light of the fact that relatively little is still known about the economic status of this particular community in the $19^{\text {th }}$ century, the list provides us with valuable data.

\section{General description of the document}

The plain cream-coloured sheet of paper folded into two halves $(350 \times 210 \mathrm{~mm})$ contains a table consisting of three columns. The last column is divided into two sub-columns, but only the first one contains text. The table has been drawn up on the first folio recto and verso and on the second folio recto. The folio 2 verso remains empty. The handwriting is careful and clearly legible. The text is written in a semi-cursive variant of the Hebrew script in light brown ink. The manuscript is in almost perfect condition, apart from a few slight wrinkles. In some places, traces of iron gall ink corrosion are visible (the ink has bled through to the other side of the sheet causing brown-coloured stains, but this does not pose any difficulties to the reader).

The table has been drawn up in four languages: Hebrew, Karaim, Polish and Russian. There is no general title for the document as a whole. The headings of the columns are in Hebrew. In column 1 we find the names of Karaites and, although not in all cases, their titles, attributes, and information on their kinship relations. Column 2 contains information on whether the relevant person owned a house or other properties. Column 3 informs us of the profession and sources of livelihood of the respective person. The content of column 1 is

\footnotetext{
${ }^{2}$ A critical edition of altogether 20 of those letters was published by Németh. See: NéMETH (2010, 2011, 2012, 2013a, 2013b), cf. also Németh (2009).
} 
in Hebrew (with the exception of line 30 and 31 on folio 1 verso, which is in Russian). The content of column 2 is in Karaim and the content of column 3 is mainly in Russian. The text in column 1 is not vocalised (with a few exceptions). In columns 2 and 3, the texts are mostly vocalised. However, in the further part of the document some recurring words have been written without vocalisation.

\section{Dating the document}

The exact date when the document was written is unknown. Fortunately, however, we have at our disposal other documents which allow us to establish the approximate date of its writing. In the community's archive there are two census record lists prepared in 1834 and $1858 .^{3}$ Both contain most of the names we find in the analysed manuscript. Another useful document is a list of Lutsk Karaites who died in 1853-1855 (AGKE/VII/22/14), compiled in 1874 by Simha Leonowicz, the hazzan in Lutsk at that time.

Namely, bachelor Mordekhay the son of Nisan Mordkov mentioned in lines 16-17 on folio 2 recto, appears in the census list for 1858 as Мордко Нисанов Мордковичь (No. 39) with the annotation "added [as a member of the Lutsk community] in 1854 ". ${ }^{4}$ This means that the list could not have been compiled earlier than 1854 . The time scale can be narrowed to this particular year, as Shemoel the son of ribbi Yaaqov, whom we find mentioned in line 2 of folio 2 recto is mentioned in the census list for 1858 as Самуилъ Якововъ Бизиковичь (No. 24) with the annotation that he died in 1854. And indeed, on the list of persons deceased between the years 1853 and 1855, the date of the death of Shemoel the son of ribbi Yaaqov is recorded as $4^{\text {th }}$ Kislev 5615 (November 25, 1854). Putting these pieces of information together, we can say

\footnotetext{
3 “Ревизская Сказка 1834 года Апреля дня [...] волынской Губернии Уезднаго Казённаго Города Луцка о состоявших в отом Караимах Купцах и Мещанах” (AGKE/ VII/14); “Ревизская Сказка / Тысяча восемсотъ пятьдесятъ восьмаго года мая восьмого дня, Волынской Губерній Города Луцка о состоящихъ мужска и женска пола Мъщанах Караимахъ” (AGKŁ/VII/13). Both documents contain also data from previous censuses held respectively in the years 1816 and 1850.

${ }^{4}$ He arrived to Lutsk from Kukizów. According to his son, Aleksander Mardkowicz (18751944), Mordekhay's father Nisan was the last member of the once flourishing Kukizów community. After his demise his wife and children moved to Lutsk. See Zarachowicz 1936, MARDKOWICZ 1932.
} 
with a high degree of probability that the manuscript was written not earlier than in January and not later than in November of 1854 .

\section{Author}

The manuscript is not undersigned, and there are no annotations that could help identify the person who compiled the list. It was undoubtedly intended for the internal needs of the community, and it is obvious that its author must have been a community member. He refers to Yaaqov the father of Shemuel and Shalom Avraham noted in line 14 on fol. 1 verso as to 'my master and my teacher', but this fact does not reveal his identity.

However, when we compare the analysed document to letter No. 7 (82) edited by NÉmeth $(2011,381)$, we can see striking similarities as far as the form and size of the letters, and the angle of the writing are concerned. Closer examination of the manuscripts allows us to suppose that both were written by the same person, i.e. Yișhaq the son of Zarah Bezikowicz, who undersigned the above-mentioned letter. In the analysed manuscript we find him noted in lines 6 and 7 on fol. 2 recto as Yiṣhaq the son of the honoured sir and ribbi Zarah. Born c. 1807, he is listed together with his wife Sionia and their six children in the census list for the year 1858. The date of his death is unknown.

Németh notes that the lexicon of the author of letter No. 7 (82) exhibits strong Slavonic influences (NÉMETH 2011, 152). This supports our hypothesis since the analysed manuscript also contains quite a large number of Slavonic elements.

Additionally, worthy of mention is the fact that his eldest son Zarah moved to Odessa, where he established a shoe shop in 1860 . One of the letters edited by Németh, namely letter No. 3 (78), was written by Zarah's younger brother Mordekhay on stationery belonging to the establishment (NÉMETH 2011, 235).

\section{Content of the manuscript}

The list, drawn up in the form of a table, contains 40 unnumbered positions separated by horizontal lines. In each row, we find data referring to one or more (up to four) persons. Those grouped together are generally related or affined to one another, and their family relations are more or less precisely determined. In total, there are 54 persons ( 52 men and two women) on the list. 


\subsection{Column 1}

\subsubsection{Names and surnames}

From among the persons enumerated, 42 are mentioned by their first name and surname, one person by his first name and father's name, eight by their first names only, two merely by their affinity to other persons (brother or father), and one person's identity is hidden under the previously-mentioned acronym. From among those mentioned by name and surname, twenty-two are additionally identifiable by their father's name - in one instance in the patronymic form Novahov (נפוֹסוֹ).

First names are written according to the original Hebrew spelling rules with the exception of Shimon (שימומן) in line 26 of folio 1 verso. ${ }^{5}$ In line 5 of folio 1 recto, we find the abbreviation שיש, which has been used to note the name of Shalom Kaliski's father: Simḥa Yișhaq (שמחה יצחק). A similar abbreviation (שמ̃יצ), referring to the same person, appears in letters No. 7 (82) and 2 (77), edited by Németh (NÉMETH 2011: 155, 224).

There are nineteen family names of Lutsk Karaites mentioned in the manu-

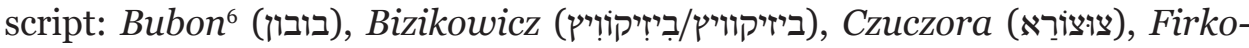

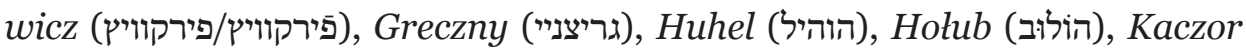

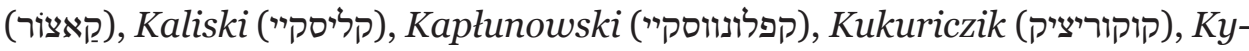

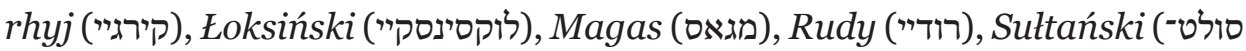

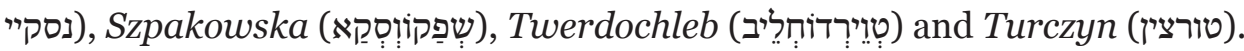

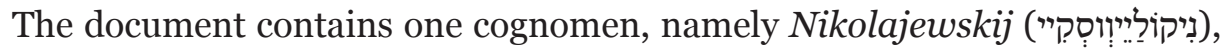
derived from a toponym (Nikolayev, rus. Николаев, ukr. Миколаїв, a city in southern Ukraine) and one patronym used as a last name, Mordkow (מורדקוו), i.e. the son of Mordko/Mordekhay.

Family names are written consistently in almost all cases. Firkowicz, a frequent family name in Lutsk, in five instances is written as פירקוויץ and in two with an additional rafe above pe as פירקוויץ.

5 The same person appears in the 1834 and 1858 census lists as Шимонъ (No. 19). This indicates that the spelling reflects the pronunciation.

${ }^{6}$ Most surnames in the document are not-vocalized. In ambiguous cases, we can attempt to reconstruct, to some extent, the pronunciation of them, based on the census list for the year 1858 and the registrar records for the years 1871-1947 (both written in the Cyrillic script) and documents from the interwar period, in which surnames are noted in Polish orthography. We have decided to cite the surnames based on the contemporary Polish spelling system. 
Family names with typical Slavonic endings are mostly written in their Ukrainian or Russian form, that is with the endings $-i j$, $-y j$ instead of the Polish -i, -y: Grecznyj, Kaliskij, Kaptunowskij, Loksynskij, Rudyj, Sultanskij.

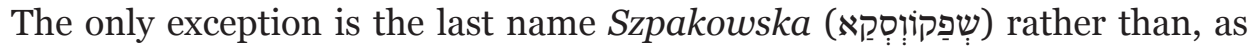
could be expected, Szpakowskaja. The surnames Hotub, Huhel also reflect the Ukrainian rather than the Polish and Russian forms Golub/Golub, Gugel/ Gogel/Gogol noted in the registrar records for the years 1871-1947. ${ }^{7}$ The same forms (with the exception of Suttanskij) are attested in the letters edited by NÉMETH (2011, 128-129).

From among the surnames listed, five appear vocalized, similarly to the cognomen. Unlike the case of the moniker, which might have been less known and thus vocalization would have eased understanding, it is difficult to explain convincingly why these particular last names have been vocalized and others not. The surname Szpakowska is not typical of Lutsk, and perhaps this fact caused the scrivener to vocalize it. As far as the family name Kaczor (קָאָצוֹר) is concerned, a need to distinguish two forms could be due to the fact that on the census list for 1858 we find Качоръ (No. 9) and Качуръ (No. 21), so vocalization in this case could have had a distinctive function. However, the first form does not appear in the manuscript at all. On the other hand, in the above-mentioned census list, we find Локиинский (No. 10, 11 and 12) attested also in the form Лукшинский (No. 36), but in the analysed manuscript this surname remains in a non-vocalized form לוקסינסקיי, and it is not possible to determine whether it was written with i or $\%$ The same applies to the surname Sultański, which in the census list for the year 1858 is written Soltanskij. The surname Bizikowicz (ביזיקוויץ), which is at least as frequent in Lutsk as Firkowicz, is noted in seven instances, but it is vocalized only once (ביזיקוֹיקווֹיץ), and surprisingly, when it appears for the second, rather than the first time. However, in this particular case, all elements, i.e. the first name, the patronym, and the

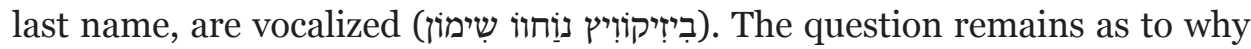
surnames typical of Lutsk, though not so frequent, e.g. Holub, Twerdochleb, Czuczora,${ }^{8}$ were vocalized. All in all, the above clearly shows that, for the time being, there is no rule that would describe the practice of vocalizing surnames.

\footnotetext{
7 AGKŁ VII/17, VII/17a, VII/19, VII/19a, VII/20 and VII/20a.

${ }^{8}$ In the census lists for the year 1834 and 1858 this surname is noted as Čičera (Чічера). Moreover in registrar records we find it noted in 1872 as Čос̌оra (Чочора). The alveolar
} 
The notation of the surname לוקסינסקיי with two samekh is rather unusual, as in manuscripts from Halicz and Lutsk it is generally spelled as (לוקשינסקי), and in the census lists it is noted as Lokšynskij/Lukšynskij. This could indicate that the surname could be pronounced Loksynskij.

Worth mentioning is also the fact that two surnames which in the census list for 1858 appear in an "ennobled" form - Tverdohlebov and Kirilovic (Kirgilovič in the census list for 1834) - in the manuscript are written in their "common" form, Twerdochleb and Kyrhyj. The surname Kukuriczik, in turn, is present in its "common" shape both in the analysed manuscript and in the census lists, but in letter $51^{\mathrm{II}}$ (written sometime between 1855 and 1868) it appears in its Russified form, Kukuriczkin (NÉMETH 2011, 257).

\subsubsection{Hebrew honorifics and titles}

Hebrew honorifics and titles, which were used by Karaites with great frequency, in this particular document are relatively rare, with the exception of כמ̃ע (the abbreviated form of כבוד מעלת) 'Honourable sir' we find in 21 instances.

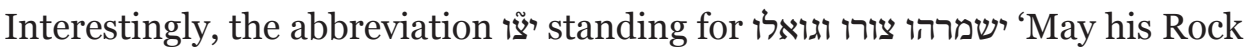
and Saviour guard him!', ${ }^{9}$ which is also quite frequent in Karaim texts, appears only twice, referring each time to members of the Huhel (Gogol) family, namely to Yaaqov the father of Shemoel and Shalom, and to David, whom we find in census lists as Yaaqov's brother (see folio 1 verso lines 15 and 22).

Another Hebrew abbreviation, namely זכרונו לברכה may his memory be blessed; of blessed memory', appears only once (see line 2 on folio 2 recto), in reference to ribbi Yaaqov, the father of Shemoel (Bizikowicz). Although it could be applied also to Shemoel Bizikowicz, the father of Avraham ${ }^{10}$ (see lines $36-39$ on folio 1 verso), since the mother is mentioned as "the widow".

pronunciation of tsade is typical for Crimean Karaim. It was quite frequent in Lutsk Karaim, though (Németh 2011, 27).

9 Or possibly ישמרהו צורו ויחיהו "May his Rock guard him and keep alive”.

${ }^{10}$ It seems that in this particular case the scrivener erroneously transposed the names, since there is no Avraham son of Shemoel in the census list for 1858; however, we find there Самуилъ Абрамовичъ (Shemoel the son of Avraham) together with his widowed mother Слоня (a diminutive form of Shelomit) and two younger brothers, 3apaxъ (Zarah) and Яковъ Шимонъ (Yaaqov Shimon) among the members of the Bezikowicz family (No. 20). 
In the text, we find a few other Hebrew honorifics and titles, e.g. בחור 'bachelor' (abbreviated as בٓ), אדוני מורי 'my master, my teacher' (abbreviated as באר 'רז),

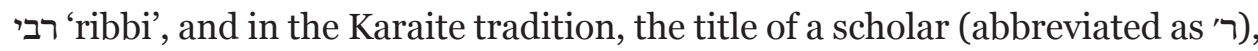
גבירה 'lady' (abbreviated as 'lady' (abbreviated as 'מרת 'la). The kinship relations are described in Hebrew with the exception of lines 30 and 31 on fol. 1 verso, where we find dwurodnij[e] bratia (Rus. двоюродные братья 'first cousins'). In two instances, the persons mentioned are described as נער 'boy'; the expression is used to refer to David the son of Yiṣhaq Turczyn and the above-mentioned son of Shelomit the widow, aged respectively ten and twelve at the time the document was written.

In the $35^{\text {th }}$ row of the table (folio 2 recto) there is no name, just the acronym רמאבמ"ר, whereas in the $3^{\text {rd }}$ column the profession of this person has been described as עבד קה"the servant of the Holy Community'. Undoubtedly, this particular expression refers to a hazzan and the acronym can be deciphered as: Ribbi Moshe Avraham ben Mordekhay. According to a list of hazzans in Lutsk published in Karaj Awazy (RibBiŁER 1932), Yuhuda Magas officiated as hazzan until $1853^{11}$ and was followed in the office by Moshe Avraham Turczyn, although there is no time range given next to Turczyn's name, just the year 1868. In the same year, his duties were taken over by Yeshua Leonowicz, a newcomer from Halicz, who remained in office until 1870.

\subsubsection{Identification of the persons mentioned in the manuscript}

The identification of the persons listed in the analysed manuscript, even those noted without their surnames, does not cause major difficulties since we have the census lists at our disposal. For instance, on folio 1 verso in lines 10-11 we find Aharon the bachelor, his brothers Moshe and Avraham and their brother Eliezer. Although neither their surname nor their father's name is written down, we can identify them as the sons of Pinhas Aronov Pilecki, noted in the census list for 1834 (No. 39) together with his two sons: Aron, age six, 5-month-old Moisei, and his nephew, Eliazar Nisanov Nowicki ${ }^{12}$, age 11.

${ }^{11}$ According to the list of persons deceased in 1853-1855, hazzan Yehuda the son of Moshe passed away on the $29^{\text {th }}$ of Heshvan 5614 (November 30,1853 ).

12 We find his signature under a letter dated October 15, 1857 and sent from Trysten in the vicinity of Lutsk, inviting the hazzan to come in order to slaughter animals in the prescribed ritual manner. The document written in Polish was published by MARDKOWICZ (1933, 5-6). 
The order in which the community members are listed in the document does not match the order in the census lists, which are arranged according to financial criteria. Five families from among those enumerated in the census list for the year 1858 are missing in the manuscript: three that have lost their male head since the previous census in 1850 and had no other male member, one consisting of one person, Samuil Novachov Łukszyński, and that of Jevšia Abramovič Leonowicz, a newcomer from Halicz, who joined the community in 1855. It is impossible to establish any general rule as far as the order is concerned, since we do not know for what the analysed list was intended.

In lines 16-17 on folio 1 recto we find Avraham Moshe Firkowicz titled as פרנס (Hebr. 'community leader, community elder'). In letter $52^{\text {II }}$, edited by Németh, the same person appears as Avraham Moshe kahatnyj (kahatnyj: 'principal, senior of the Karaite community'), and since the content of the currently analysed document was not known at the time of Németh's edition, he identified him erroneously as Avraham Moshe Gołub (Németh 2011: 332). We can now say that Avraham was also the person who undersigned the letter edited by Németh, putting his signature just below the signature of hazzan Moshe Avraham Turczyn (Németh 2011, 256).

\subsection{Column 2}

At the top of the list, we find Moshe Magas together with his brother, who can be identified as Solomon (Shelomo). The Magas brothers are noted as the owners of a garner, a small house with an abattoir, a house with a mill and land. Their father, Avraham the son of Moshe, the younger brother of the previously-mentioned hazzan Yehuda Magas, is not listed, though he was still alive at this time. ${ }^{13} \mathrm{He}$ was the wealthiest Karaite in Lutsk; therefore, he appears at the top of the census lists. In the list for 1834 , he is described as a " $3^{\text {rd }}$ guild merchant" with an annotation that during the previous census in 1816 he was still listed among the burghers. J. Sulimowicz mentions in his private notes that according to a contract dated Sivan 5592 (1832), Avraham Magas was the lease-holder of horse changing stations in Młynów and Warkowicze in the vicinity of Dubno. ${ }^{14} \mathrm{We}$ find him in the inventory list of the Lutsk prayer

\footnotetext{
${ }^{13}$ According to the list of persons deceased in 1853-1855, he passed away on the $19^{\text {th }}$ of $A v$ 5615 , i.e. on July 22, 1855 , according to Julian calendar (August 3, 1855, according to the Gregorian account).

${ }_{14}$ Unfortunately, we are not able to identify this document.
} 
house $^{15}$ as the donator of a Torah scroll in 1829. In 1853, he decorated this scroll with eight silver plaques engraved with the names of the members of his family and placed it in a silver covered case with silver handles.

Yaaqov Gugel, the second on the census lists, does not appear in the analysed document. However, in lines 13-15 on fol. 1 verso, we find his sons Shemoel and Shalom-Avraham. Surprisingly, they do not own a house as might be expected judging by their father's relatively high position as the " $33^{\text {rd }}$ guild merchant".

Shalom the son of Simḥa Yișhaq Kaliski (line 5) and David the son of Yișhaq Turczyn (line 21 on fol. 1 recto) own one piece of land each, but there is no information what kind of land this was.

From among the persons listed, twelve were the owners of houses. One of them, namely Yișhaq Kapłunowski, even had two in his possession. The Magas brothers shared a house next to mill and owned also a small house with an abattoir arranged inside. Two other persons owned half a house each - Shalom Firkowicz inherited it from his father Avraham (line 17 on fol. 1 recto), and the other half came into Yișhaq Nisan Firkowicz's possession as dowry for his wife (fol. 1 recto line 6). Since Yișhaq Nisan's spouse Ruhama was the daughter of Avraham, most probably they shared the house. Next to the name of Yosef Shelomo Firkowicz, we find the intriguing information that he owns a house, but it belongs to sir Moshe the elder. Unfortunately, we do not know how Yosef became the owner of the house and what his relation was to sir Moshe, whose identity remains unknown.

As can be seen from the above, in Lutsk in the mid- $19^{\text {th }}$ century, there were twelve houses in the possession of Karaites. We cannot ascertain whether the houses were located in Lutsk or in its vicinity, since a relatively large group of Lutsk Karaites used to live outside the city in the surrounding villages and farmsteads. ${ }^{16}$

\subsection{Column 3}

The language of this part of the document is Russian (with the exception of the Karaim bezirgen 'the merchant' in line 5 and Hebrew עבד קה"ק in line 8 on fol. 2 verso), however, it exhibits the visible influence of Polish and Ukrainian as far as vocabulary (šinkar, reznik) and pronunciation (usluhami) are

\footnotetext{
15 AGKE VII/22/o3.

${ }_{16}$ The list of the villages with Karaite inhabitants published in Karaj Awazy, most probably by Mardkowicz, contains forty names. See SIFCEGI 1933.
} 
concerned. We will not discuss here peculiarities concerning the spelling and pronunciation of the Russian words, since it is not the subject of this paper. We would like merely to mention that it seems that the use of Slavonic lexemes here might have been guided by the lack of adequate terminology and by the author's insufficient knowledge of the Karaim language. As was mentioned above, a strong Slavonic influence is a characteristic feature of Yișaq the son of Zarah Bizikowicz's style of writing.

There are five professions noted in the analysed manuscript: šinkar (משינְקר)

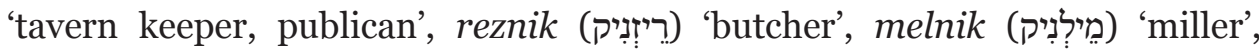

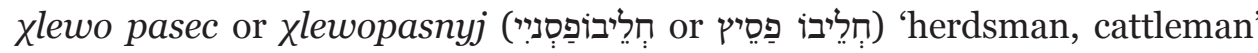
and bezirgen (ביזיְרֵֵין) 'merchant'. The most frequent profession among Lutsk Karaites, held by eleven of the persons mentioned, were publicans. They are followed by butchers - six persons held this profession, and millers - there were three among the community's members. One person had a double profession: Zekharya Turczyn (line 9 fol. 2 recto) was a publican and a butcher. From among the millers, two were father and son: Yaaqov Yișhaq and his son, who can be identified as Yaaqov Yișhaq the son of Nisan Kaczor and Shemoel, his son from his first marriage. According to the list, the hazzan had no other occupations aside from his religious duties.

Surprisingly, none of the two Karaim " 3 rd guild merchants" in Lutsk is mentioned as a merchant, while there is a reference to Yișhaq the son of Simha Bizikowicz (lines $3-5$, fol. 2 recto). His monicker Nikolajevskij alludes to the city of Nikolayev (present-day Mykolaiv), where he must have spent some time, since among the letters edited by Németh we find letter No. $52^{\mathrm{II}}$ written most probably by him and sent from this city in $\mathbf{1 8 5 3}$.

Two persons are listed as being a herdsman or a cattleman, namely the previously mentioned Eliezer Nowicki and Mordekhay, the brother of Shalom Kukuriczik (line 9 on fol. 1 verso). Next to the name of the latter, we find an intriguing

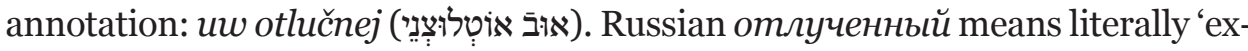
communicated'. In this particular case, we do not know if it means a temporary excommunication from the community for some unknown reasons or just living apart (Polish odtaczony 'disconnected, separated'). However, on the list of subscribers for I. Sinani's Исторія возникновенія и развитія караимизма $(1888,112)$, we find Mordekhay Kukuručkin (sic!) living in Odessa. 
The main sources of livelihood are described as being farming, which concerns two persons, namely the Magas brothers, owning a leasehold property (seventeen persons, among them six who had another source of livelihood or profession), being engaged in individual services (eight persons, among them four who were also leaseholders). The livelihood of Sara Szpakowska, the only woman listed, was provided by her relatives with whom she probably shared the house she owned. One person, namely the previously-mentioned young David Turczyn is described as being in college (Rus. училище) and engaged in handicraft - his case is quite difficult to explain, as we have no information on his further life. The question whether he was a student of a high school or an apprentice, and later, in what kind of craft he was engaged, remains open. Likewise, the leasehold estates and the services exercised by Lutsk Karaites remain unknown. However, as far as Yiṣhaq the son of Avraham Moshe Holub being listed as a miller and leasehold owner, we may assume that he leased a mill, especially when we take into consideration the fact that in the interwar period his son, Michał (Moshe-Avraham) Gołub was a mill leaser in Czekno in the vicinity of Lutsk.

\section{Conclusion}

The content of the analysed documents shows that in the mid- $19^{\text {th }}$ century, farming had not been for a long time the main occupation of the Lutsk Karaites, if it ever was. The most frequent source of their livelihood was leasehold - owned by one third of the persons mentioned, and indefinite private services executed by almost 15 percent of them. From among 50 adult men listed, 22 percent are shown as tavern keepers, 12 percent as butchers. Comparing this data to the results of a survey of 1851 concerning Zhitomir (a town larger than Lutsk but with a similarly sized Jewish population), which shows that 39 percent of the local Jews as inn and tavern keepers, 25 percent as tradesmen and shopkeepers, and 21 percent as craftsmen (Gartner, 2001, 188), we see that Karaites were less active in trade and crafts than Rabbanite Jews, although they were relatively often involved in professional activity that was popular among Jews, such as tavern keeping. 


\section{Text}

Fol. 1 recto

\begin{tabular}{|c|c|c|c|}
\hline משא מתניהם ומלכאתם & עזבוניהם ובתיהם המוחזקים & קביעת שמות האנשים & [1] \\
\hline זַנְימִייוּטְסַא & 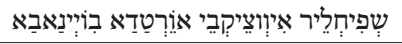 & 'כמעי17 משה מגאס עם אחיו & [2] \\
\hline חַזיַיְסְטְווֹם & 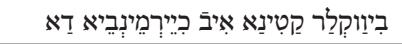 & & [3] \\
\hline & גְרוּנְטְלְרְבַא & & [4] \\
\hline שִינְקַר & בִיר גְרְוּנְטוּ בַרְדִי & שלום בן שזי18 קליסקיי & [5] \\
\hline ריזיזנִיק & בַרְדִי יַיירים אִיבְי קַטִינִיסַרְי & יצחק ניסן פירקוויץ & [6] \\
\hline רִיזְנִיק & בַרְדִי אִיבְי & כמע שמואל בן אהרן קירגיי & [7] \\
\hline רֵיזְנִיק & בַרְדִי אִיבְי & ב'19 משה בן שמחה פירקוויץ & [8] \\
\hline סוֹדַירזְזיט & בַרְדִי אִיבְי & כמע יצחק משה גריצניי & [9] \\
\hline אוֹבְרוֹצְנִיי & & & {$[10]$} \\
\hline 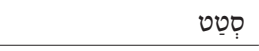 & & & {$[11]$} \\
\hline שִינְקַר & יוֹחְטְוּ אִיבי & כמ̃ע משה צוּצוֹרַא & {$[12]$} \\
\hline סוֹדַירְְזיט & בַרְדִדי אִיבִי & כמע שמחה יצחק לוקסינסקיי & {$[13]$} \\
\hline אוֹבְרוֹצְנִיי & & & [14] \\
\hline סְטַטֵיי & & & {$[15]$} \\
\hline אִי רִיזְנְיק & & & {$[16]$} \\
\hline שִינְקַר & יִירִים אִיבְי אַטַסִינְדַן & כמ̃ע שלום בן אברהם פירקוויץ & {$[17]$} \\
\hline סוֹדֵירְזִיט & יוֹחְטוּ אִיבַי & כמע אברהם משה פירקוויץ & {$[18]$} \\
\hline אוֹבְרוֹצְנִיי & & פרנס & [19] \\
\hline 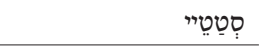 & & & [20] \\
\hline וְוא אוּצִילִישְצֵי & בִיר גְרְוּנְטוּ בַרְדִי & הנער דוד בן יצחק טורצין & {$[21]$} \\
\hline זַנְנימִייטְסַא & & & {$[22]$} \\
\hline רוּקוֹדֵילִים & & & {$[23]$} \\
\hline מִילְינִיק אִי & בַרְדִדי אִיבַי & כמ̃ע יצחק בן אברהם משה & {$[24]$} \\
\hline סוֹדֵירְִזיט & & הולוּב & {$[25]$} \\
\hline אוֹבְר אוֹצְנְייַא & & & {$[26]$} \\
\hline 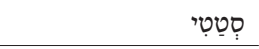 & & & {$[27]$} \\
\hline רִיְנְנִיק & אֵֵיכִי אִיבַי & כמעע יצחק הזקן קפלונווסקיי & {$[28]$} \\
\hline סוֹדֵירְִזיט & יוֹחְטוּ אִיבְי & כמע משה הזקן רודיי & [29] \\
\hline אוֹבְרוֹצְנִיי & & & [30] \\
\hline 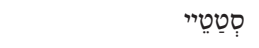 & & & [31] \\
\hline
\end{tabular}

17 כמע: A frequent abbreviation standing for כבוד מעלת 'honourable sir'. In further part of the text as כמעע.

שי An שמחה יצחק (Simha Yișaq).

ב' Abbreviated בחור :young men', in Karaite tradition stands for 'bachelor'. 
Fol. 1 verso

\begin{tabular}{|c|c|c|c|}
\hline סוֹדַיְרְזַט אוֹבְרוֹצְנִיי & יוֹחְטוּ אִיבְלֵירִיר & יעקב עם אחיו אליה & [1] \\
\hline סְטַטִי & & ביזיקוויץ & {$[2]$} \\
\hline \multirow[t]{2}{*}{ שִינְקָרר } & בַרְדִי אִיבְי אַלֵי אוֹל אִיבב & כמעע יוסף שלמה פירקוויץ & [3] \\
\hline & כמעע משה הזקן נִין דִי & & [4] \\
\hline שִינְקַרר & יוֹחְטוּ אִיבְי & שלום בן יוסף קוקוריציק & [5] \\
\hline 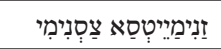 & יוֹחְטוּ אִיבְי & אחיו אברהם & [6] \\
\hline אוּסְלוּהַמִי & בַרְדִי אִיבְי & יחזקאל & [7] \\
\hline חְלְיבוֹפַסְנִיי & & & {$[8]$} \\
\hline אוּב אוֹטְלוּצְנֶי & יוחְְטוּ & מרדכי & [9] \\
\hline זָנְימַיייטְסַא צַסְטְנְימִי & יוֹחְטוּ אִיבְלִירִי & ב' אהרן אחיו משה אברהם & {$[10]$} \\
\hline אוּסְלוּהַומִִי & & & [11] \\
\hline חְלֶיבוֹ פַסֵיץ & יוֹחְטוּ אִיבי & אחיהם אליעזר & {$[12]$} \\
\hline סוֹדָיְרְזַאט אוֹבְרוֹצְנִיי & יוֹחְטוּ אִיבְלִירִי & כמ̃ע שמואל ושלום אברהם & {$[13]$} \\
\hline \multirow[t]{2}{*}{ סְטַטַי } & & בני אזמ20 כמע יעקב & {$[14]$} \\
\hline & & הזקן יצ̃ן21 הוהיל & {$[15]$} \\
\hline \multirow[t]{2}{*}{ מֵילְנִיקִי } & יוֹחְטוּ אִיבְלִירִי & כמע יעקב יצחק הזקן & {$[16]$} \\
\hline & & עם בנו & {$[17]$} \\
\hline \multirow[t]{2}{*}{ שִינְקַר } & יוֹחְטוּ אִיבְי & כמעע נח הזקן & {$[18]$} \\
\hline & & לוקסינסקיי & [19] \\
\hline 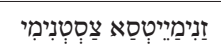 & יוֹחְטוּו & יוסף בן משה & [20] \\
\hline אוּסְלוּהַמִי & & בובון & {$[21]$} \\
\hline אוֹבְרוֹצְנְיי סְטָטֵיי & יוֹחְטוּוּ & כמ̃ע דוד יצו הוהיל & {$[22]$} \\
\hline \multirow[t]{2}{*}{ צַסְנְימִי אוּסְלוּהַמִּי } & יוחטו & יוסף בן ר־22 יצחק & {$[23]$} \\
\hline & & פירקוויץ & {$[24]$} \\
\hline שִינְנַרר & יוֹחְטוּ & ר׳ יוסף מגאס & {$[25]$} \\
\hline \multirow[t]{2}{*}{ שִשינְקַר } & יוֹחְטוּו & שִימוֹן נוֹחוֹוֹ & [26] \\
\hline & & בִיזיקוֹוִיץ & {$[27]$} \\
\hline \multirow[t]{2}{*}{ צַסְטְנִימִי אוּסְלוּהַמִי } & יוֹחְטוּ & ב' שמואל בן יעקב שמחה & [28] \\
\hline & & קַאצוֹר & [29] \\
\hline אוֹבְרוֹצְנִיייע & יוֹחְטוּ & יצחק בן משה & [30] \\
\hline סְטַטֵיי & & ביזיקוויץ & [31] \\
\hline
\end{tabular}

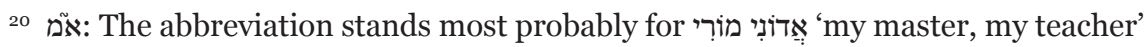

21 יצחי: An abbreviation standing for ישמרהו צורו וגואלו 'May his Rock and Saviour guard him!'.

In line 22 below we find it again, but in less legible shape.

22 :רי 2 : רבִּי Abbreviated', in Karaite tradition a title of a scholar. 


\begin{tabular}{|c|c|c|}
\hline 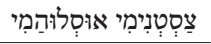 & אִיבְלְירִי יוֹק & דְבַוּ רודניי \\
\hline אִי סוֹדַירְזָט & & ברטייע \\
\hline אוֹבְרוֹצְנִייע & & זרח יצחק לוי \\
\hline סְטַטֵיי & & שמואל \\
\hline אוֹבְרְוֹצְנִיי & יוחטו & נערי כמעע אברהם \\
\hline \multirow[t]{3}{*}{ סְטַטֵיי } & & בן שמואל ביזיקוויץ \\
\hline & & אמם ג'23 שלומית \\
\hline & & האלמנה \\
\hline
\end{tabular}

Fol. 2 recto

\begin{tabular}{|c|c|c|c|}
\hline שִשינְקַר & יוחטו איבי & ב' שמחה סולטנסקיי & [1] \\
\hline & יוחטו & שמואל בן ר׳ יעקוב ז־ל24 & [2] \\
\hline & & יצחק בן שמחה & [3] \\
\hline צַסְטְיְינִימִי אוּסְלוּהַמִי & יוחטו & ביזיקוויץ נִיקוֹלַייְוְוְסְקִיי & [4] \\
\hline בַיְזירְגֵין & & & {$[5]$} \\
\hline סוֹדַירְזיט אוֹבְרוֹצְנוֹיי & יוֹחְטוּ & כמעע יצחק בן כמ̃ר & [6] \\
\hline סְטַטֶיי & & זרח ביזיקוויץ & [7] \\
\hline עבד קהזק25 & יוחטו & רמאבמר26 & [8] \\
\hline שִינְקַר רֵיזְנִיק & יוחטו & זכריא טורצין & [9] \\
\hline סוֹדֵיִרְזיט אוֹבְרוֹצְנְיוי. & יוחטו & כמעע נח יעקב פירקוויץ & {$[10]$} \\
\hline סְטַטֵיי & & & {$[11]$} \\
\hline \multirow[t]{2}{*}{ שִינְנַקר } & יוחטו & כמעע שלום בן ניסן & {$[12]$} \\
\hline & & טְוְירדוֹֹ חְלֵיב & {$[13]$} \\
\hline \multirow[t]{2}{*}{ ריזניק } & יוחט & ב' מרדכי בן ניסן & {$[14]$} \\
\hline & & מורדקוו & {$[15]$} \\
\hline \multirow[t]{2}{*}{ פְרִירוֹדְנִיח } & בַרְדִי אִיבִי & מי27 שרה הזקנה האלמנה & {$[16]$} \\
\hline & & שְפַקוֹוְסְקַא & {$[17]$} \\
\hline
\end{tabular}

23 ג'וג Abbreviated גבירה 'lady'.

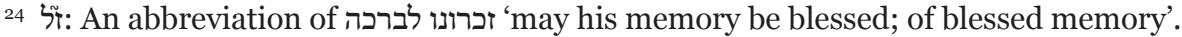

25 קהזי: An abbreviation standing for קהלת קדבר 'Holy Communities'

${ }^{26}$ The acronym רבאז Ribbi Moshe Avraham ben Mordekhay'.

27 מ' 27 : Abbreviated מרת'. 


\section{Translation}

\section{Fol. 1 recto}

\begin{tabular}{|c|c|c|c|}
\hline [1] & $\begin{array}{l}\text { A list }{ }^{28} \text { of names } \\
\text { of the people }{ }^{29}\end{array}$ & $\begin{array}{l}\text { Their estates and the } \\
\text { houses owned by them }\end{array}$ & Their trades and crafts \\
\hline [2] & Honourable sir Moshe & A garner together with a small & They are engaged \\
\hline [3] & Magas and his brother & $\begin{array}{l}\text { house with an abattoir inside } \\
\text { near bivouacs }{ }^{30} \text { a house } \\
\text { together with a mill }\end{array}$ & in farming \\
\hline [4] & & and a piece of land & \\
\hline [5] & $\begin{array}{l}\text { Shalom the son of } \\
\text { Simḥa Yișhaq Kaliskij }\end{array}$ & He owns a piece of land & The publican \\
\hline [6] & Yiṣhaq Nisan Firkowicz & $\begin{array}{l}\text { He owns half of a house } \\
\text { thanks to his wife }\end{array}$ & The butcher \\
\hline [7] & $\begin{array}{l}\text { Honourable sir Shemoel } \\
\text { the son of Aharon Kyrhyj }\end{array}$ & He owns a house & The butcher \\
\hline [8] & $\begin{array}{l}\text { Moshe the bachelor, the } \\
\text { son of Simha Firkowicz }\end{array}$ & He owns a house & The butcher \\
\hline [9] & $\begin{array}{l}\text { Honourable sir Yișhaq } \\
\text { Moshe Grecznyj }\end{array}$ & He owns a house & He owns \\
\hline $\begin{array}{l}{[10]} \\
{[11]}\end{array}$ & & & $\begin{array}{l}\text { leasehold } \\
\text { properties }\end{array}$ \\
\hline$[12]$ & $\begin{array}{l}\text { Honourable sir } \\
\text { Moshe Czuczora }\end{array}$ & He owns no house & The publican \\
\hline$[13]$ & $\begin{array}{l}\text { Honourable sir Simḥa } \\
\text { Yișhaq Loksynskij }\end{array}$ & He owns a house & He owns \\
\hline $\begin{array}{l}{[14]} \\
{[15]} \\
{[16]}\end{array}$ & & & $\begin{array}{l}\text { leasehold } \\
\text { properties } \\
\text { and [he is a] butcher }\end{array}$ \\
\hline [17] & $\begin{array}{l}\text { Honourable sir } \\
\text { Shalom the son of } \\
\text { Avraham Firkowicz }\end{array}$ & $\begin{array}{l}\text { [He owns] half of a house } \\
\text { [inherited] from his father }\end{array}$ & The publican \\
\hline$[18]$ & $\begin{array}{l}\text { Honourable sir Avraham } \\
\text { Moshe Firkowicz }\end{array}$ & He owns no house & He owns \\
\hline $\begin{array}{l}{[19]} \\
{[20]}\end{array}$ & the community leader & & $\begin{array}{l}\text { leasehold } \\
\text { properties }\end{array}$ \\
\hline
\end{tabular}

28 Literally 'setting, determining'

${ }^{29}$ I owe my sincere thanks to Professor Piotr Muchowski for his assistance and consultations in Hebraistic matters, as well as translation of the Hebrew headings.

${ }^{30}$ The meaning is unclear, probably a location in Lutsk or in its vicinity. 

son of Yișhaq Turczyn

[22]

In a school

[23]

[24] Honourable sir Yishhaq the He owns a house

engaged in son of Avraham Moshe

[25] Hołub

handicraft

[26]

[27]

[28] Honourable sir Yișhaq He owns two houses

The miller and

he owns

leasehold

properties

the elder Kapłunowskij

The butcher

[29] Honourable sir Moshe the elder Rudyj

[30]

He owns no house

He owns

leasehold

[31]

properties

Fol. 1 verso

[1] Yișhaq together with

[They] own no house

He owns leasehold

his brother Eliyya

[2] Bizikowicz

[3] Honourable sir Yosef

properties

Shelomo Firkowicz

[4] belongs to Honourable

sir Moshe the elder

\begin{tabular}{|c|c|c|c|}
\hline [5] & $\begin{array}{l}\text { Shalom the son of } \\
\text { Yosef Kukuričik }\end{array}$ & He owns no house & The publican \\
\hline [6] & His brothers Avraham & He owns no house & Engaged in private \\
\hline [7] & Yehezqel & He owns a house & services \\
\hline [8] & & & The herdsman \\
\hline [9] & Mordekhay & He owns no [house] & The separated \\
\hline [10] & $\begin{array}{l}\text { Bachelor Aharon, } \\
\text { his brothers Moshe } \\
\text { [and] Avraham }\end{array}$ & They own no house & Engaged in private \\
\hline [11] & & & services \\
\hline [12] & Their brother Eliezer & He owns no house & The herdsman \\
\hline [13] & $\begin{array}{l}\text { Honourable sirs Shemoel } \\
\text { and Shalom Avraham, }\end{array}$ & They own no house & They own leasehold \\
\hline [14] & $\begin{array}{l}\text { the sons of honourable } \\
\text { sir Yaakov }\end{array}$ & & properties \\
\hline [15] & the elder, may his & & \\
\hline & $\begin{array}{l}\text { Rock and his Saviour } \\
\text { guard him, Hohel }\end{array}$ & & \\
\hline [16] & Honourable sir Yaaqov & They own no house & The millers \\
\hline [17] & $\begin{array}{l}\text { Yișhaq the elder } \\
\text { together with his son }\end{array}$ & & \\
\hline
\end{tabular}




\begin{tabular}{|c|c|c|c|}
\hline $\begin{array}{l}{[18]} \\
{[19]}\end{array}$ & $\begin{array}{l}\text { Honourable sir } \\
\text { Noah the elder } \\
\text { Loksinskij }\end{array}$ & He owns no house & The publican \\
\hline [20] & $\begin{array}{l}\text { Yosef the son of } \\
\text { Moshe Bubon }\end{array}$ & He owns no [house] & Engaged in private \\
\hline$[21]$ & & & services \\
\hline$[22]$ & $\begin{array}{l}\text { Honourable sir David, } \\
\text { may his Rock and his } \\
\text { Saviour guard him, Hohel }\end{array}$ & He owns no [house] & Leasehold properties \\
\hline $\begin{array}{l}{[23]} \\
{[24]}\end{array}$ & $\begin{array}{l}\text { Yosef the son of } \\
\text { ribbi Yișhaq } \\
\text { Firkowicz }\end{array}$ & He owns no [house] & Private services \\
\hline$[25]$ & ribbi Yosef Magas & He owns no [house] & The publican \\
\hline $\begin{array}{l}{[26]} \\
{[27]}\end{array}$ & $\begin{array}{l}\text { Shimon Novahov } \\
\text { Bizikowicz }\end{array}$ & He owns no [house] & The publican \\
\hline $\begin{array}{l}{[28]} \\
{[29]}\end{array}$ & $\begin{array}{l}\text { Shemoel the bachelor, } \\
\text { the son of Yaaqov Simha } \\
\text { Kaczor }\end{array}$ & He owns no [house] & Private services \\
\hline $\begin{array}{l}{[30]} \\
{[31]}\end{array}$ & $\begin{array}{l}\text { Yișhaq the son of Moshe } \\
\text { Bizikowicz }\end{array}$ & He owns no [house] & Leasehold \\
\hline $\begin{array}{l}{[32]} \\
{[33]} \\
{[34]} \\
{[35]}\end{array}$ & $\begin{array}{l}\text { First } \\
\text { cousins }^{31} \\
\text { Zarah, Yișhaq, Levi, } \\
\text { Shemoel }\end{array}$ & [They] own no house & $\begin{array}{l}\text { Private services } \\
\text { and they own } \\
\text { leasehold } \\
\text { properties }\end{array}$ \\
\hline [36] & $\begin{array}{l}\text { My boy, honourable } \\
\text { sir Avraham }\end{array}$ & He owns no [house] & Leasehold \\
\hline [37] & $\begin{array}{l}\text { the son of Shemoel } \\
\text { Bizikowicz, }\end{array}$ & & properties \\
\hline [38] & $\begin{array}{l}\text { their }{ }^{32} \text { mother } \\
\text { lady Shelomit }\end{array}$ & & \\
\hline [39] & the widow & & \\
\hline
\end{tabular}

${ }^{31}$ In the census list for the year 1858 Zarah, Yișhaq and Levi are listed together with Yiṣhaq the son of Moshe Bizikowicz as the sons of his first paternal uncle (according to the census list for the year 1834 his uncle's name was Shimon - Шимонъ), as well as Samuil, Zarah and Yaaqov Shimon as the sons of his second paternal uncle (Avraham). Both uncles died before 1850 and they are not listed in 1858. In the analysed document Shemuel (Samuil) must have been erroneously noted twice. See the footnote No. 10.

Worth mentioning is the fact that Shemuel the son of Avraham, born about 1842, was the father of Abram Samoilovitch Besicovitch (1891-1970), professor of mathematics at the University of Cambridge.

${ }^{32}$ According to the census list mentioned, Shemuel Bizikowicz, noted here as Avraham, had two younger brothers. This could explain the use of a plural possessive pronoun. 
Fol. 2 recto

\begin{tabular}{|c|c|c|c|}
\hline [1] & $\begin{array}{l}\text { Simḥa the bachelor } \\
\text { Sultanskij }\end{array}$ & He owns no house & The publican \\
\hline [2] & $\begin{array}{l}\text { Shemoel the son of } \\
\text { ribbi Yaaqov, may his } \\
\text { memory be blessed }\end{array}$ & He owns no [house] & \\
\hline [3] & Yiṣhaq the son of Simḥa & & \\
\hline $\begin{array}{l}{[4]} \\
{[5]}\end{array}$ & Bizikowicz Nikolajewskij & He owns no [house] & $\begin{array}{l}\text { Private services } \\
\text { The merchant }\end{array}$ \\
\hline [6] & $\begin{array}{l}\text { Honourable sir Yișhaq } \\
\text { the son of honourable } \\
\text { sir and ribbi }\end{array}$ & He owns no [house] & \\
\hline [7] & Zarah Bizikowicz & & \\
\hline [8] & $\begin{array}{l}\mathrm{R} \text { [ibbi] M[oshe] } \\
\mathrm{A}[\text { vraham the son of] } \\
\mathrm{M} \text { [ordekhaj the] } \mathrm{R}[\mathrm{ibbi}]\end{array}$ & He owns no [house] & $\begin{array}{l}\text { The servant of the } \\
\text { Holy Community }\end{array}$ \\
\hline [9] & Zekharya Turczyn & He owns no [house] & $\begin{array}{l}\text { The publican } \\
\text { [and] butcher }\end{array}$ \\
\hline [10] & $\begin{array}{l}\text { Honourable sir Noah } \\
\text { Yaaqov Firkowicz }\end{array}$ & He owns no [house] & He owns leasehold \\
\hline [11] & & & properties \\
\hline $\begin{array}{l}{[12]} \\
{[13]}\end{array}$ & $\begin{array}{l}\text { Honourable sir Shalom } \\
\text { the son of Nisan } \\
\text { Twerdochleb }\end{array}$ & He owns no [house] & The publican \\
\hline [14] & $\begin{array}{l}\text { Mordekhay the bachelor, } \\
\text { the son of Nisan }\end{array}$ & He owns no [house] & The butcher \\
\hline [15] & Mordkow & & \\
\hline [16] & $\begin{array}{l}\text { Lady Sara the elder, } \\
\text { the widow }\end{array}$ & She owns a house & [Lives] at her relatives \\
\hline [17] & Szpakowska & & \\
\hline
\end{tabular}

\section{References}

DubiŃsKA, Anna. 1999. Garść danych o Karaimach z Łucka, Awazymyz 2 (3), 9-10. Gartner, Lloyd P. 2001. History of the Jews in Modern Times, Oxford.

GąsIorowski, Stefan. 2008. Karaimi $w$ Koronie i na Litwie $w X V-X V I I w .$, Kraków - Budapeszt.

KOZIERADZKI, Aleksander. 1962. Wspomnienia z lat szkolnych 1820-1831, WrocławWarszawa-Kraków.

MardKowicz, Aleksander. 1932. Zeretłerinde Kukizownun. Karaj Awazy 3 (5), 11-16. Mardkowicz, Aleksander. 1933. Sahyncyna “babinecnin”. Karaj Awazy 6, 1-10. 
Materiały = Eisenbach, A., Michalski, J., Rostworowski, E., Woliński, J. (eds.). 1969. Materiały do dziejów Sejmu Czteroletniego, vol. 6, 524-526. Wrocław Warszawa - Kraków.

NÉMETH, Michał. 2009. Errors with and without Purpose: A. Mardkowicz's Transcription of Łuck-Karaim Letters in Hebrew Script. Studia Linguistica Universitatis Iagiellonicae Cracoviensis 128, 69-101.

NÉmeth, Michał. 2010. North-Western and Eastern Karaim Features in a Manuscript Found in Łuck. Studies on the Turkic World. A Festschrift for Professor St. Stachowski on the Occasion of His $80^{\text {th }}$ Birthday, Mańczak-Wohlfeld E. and Podolak, B. [eds.], Kraków, 75-94.

NÉmeth, Michał. 2011. Unknown Lutsk Karaim Letters in Hebrew Script $\left(19^{\text {th }}\right.$ 20 ${ }^{\text {th }}$ Century). A Critical Edition. (= Studia Turcologica Cracoviensia 12). Kraków.

NÉмETH, Michał. 2012. A North-Western Karaim Manuscript Found in Lutsk A Case of Dialect Mingling? Studia Linguistica Universitatis Iagiellonicae Cracoviensis 129, 139-162.

NÉmeth, Michał. 2013a. Karaim Letters of Jehoszafat Kapłanowski. I. A Critical Edition. Studia Linguistica Universitatis Iagiellonicae Cracoviensis 130, 237-257; NÉmeth, Michał. 2013b. Karaim Letters of Jehoszafat Kapłanowski. II. Linguistic Analysis, ibidem, 259-276.

RibBIŁER = Ribbiłer, kajsyłar hazzanłyk ettiłer Łuckada basłap burunhu jarymyndan XIX izjilnyn, 1932. Karaj Awazy, 3 (5), 16.

SIFCEGI = Sifcegi sałałarnyn, 1933, Karaj Awazy 6, 22.

SinaNi, Isaak O. 1888. Исторія возникновенія и разитія караимизма, Simferopol.

Wiткоwsкi, Rafał. 2007. Odezwa Karaimów łuckich w czasach Sejmu Wielkiego, Almanach Karaimski, Wrocław, 57-58.

ZAJączkowski, Ananiasz. 1933. Karaimi na Wołyniu. Rocznik Wołyński 3, 1-45.

ZaRACHOWICZ, Zarach. 1936. Uruwu jaryk eltiwciłernin. Karaj Awazy 9, 2-6.

Anna Sulimowicz is a senior lecturer in the Department of Turkish Studies and Inner Asian Peoples in the Faculty of Oriental Studies of the University of Warsaw. She is the secretary of the Association of Polish Karaims (Związek Karaimów Polskich w RP). Her research interests are focused on the history of the Karaite communities in Lutsk and Halicz. She is also a teacher of Turkish and a translator of the Nobel Prize winner Orhan Pamuk's novels into Polish. 


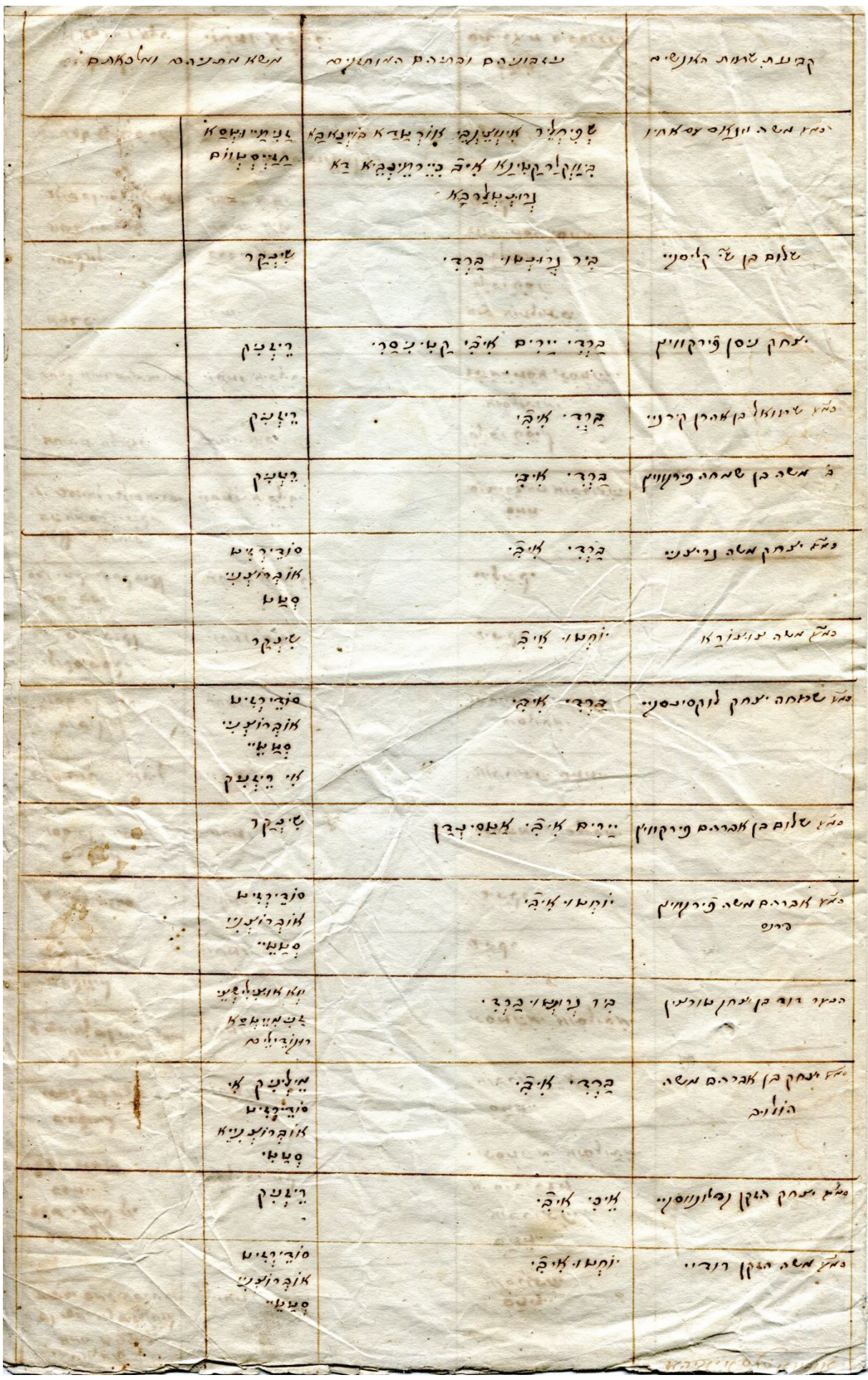




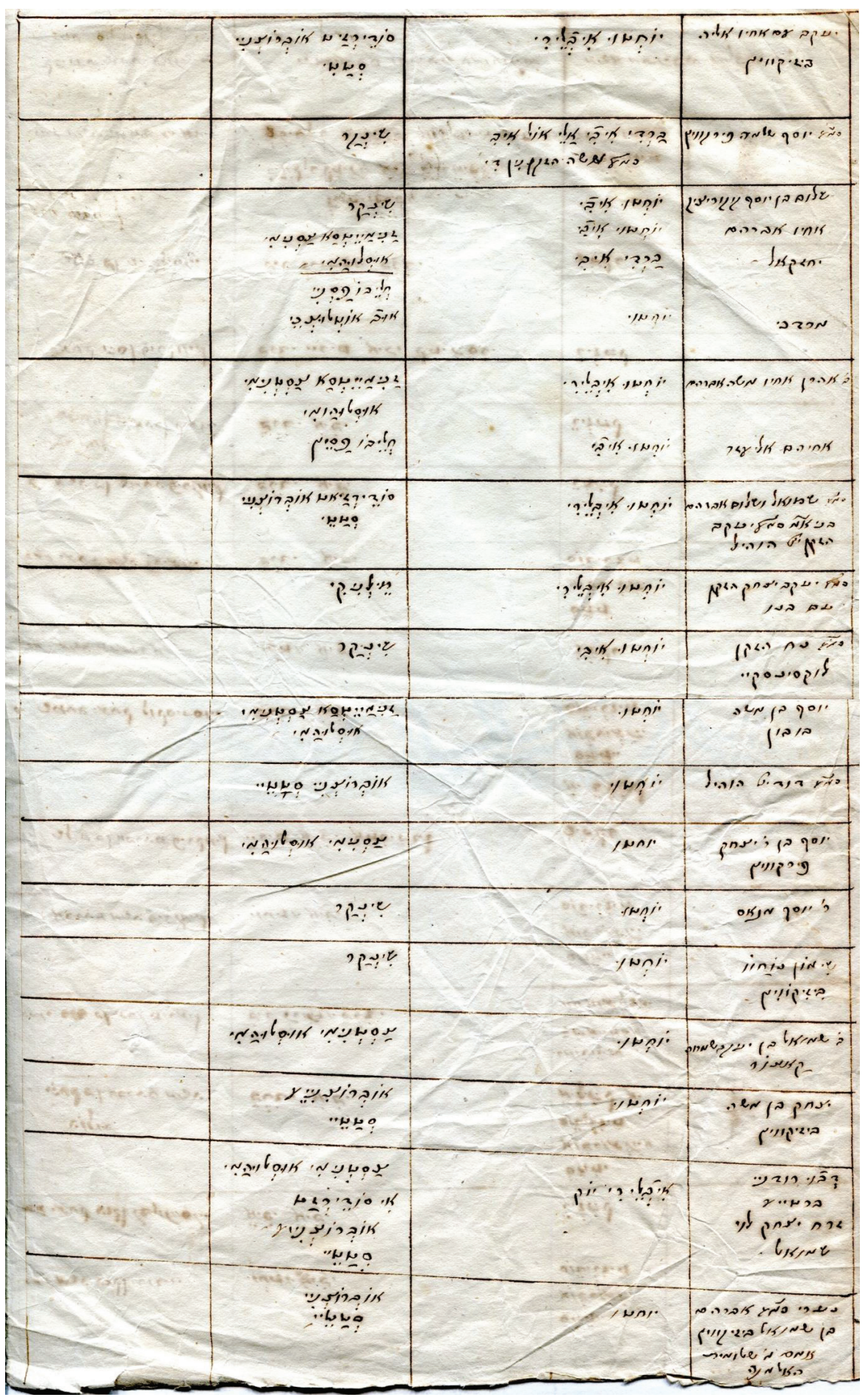

Folio 1 verso 


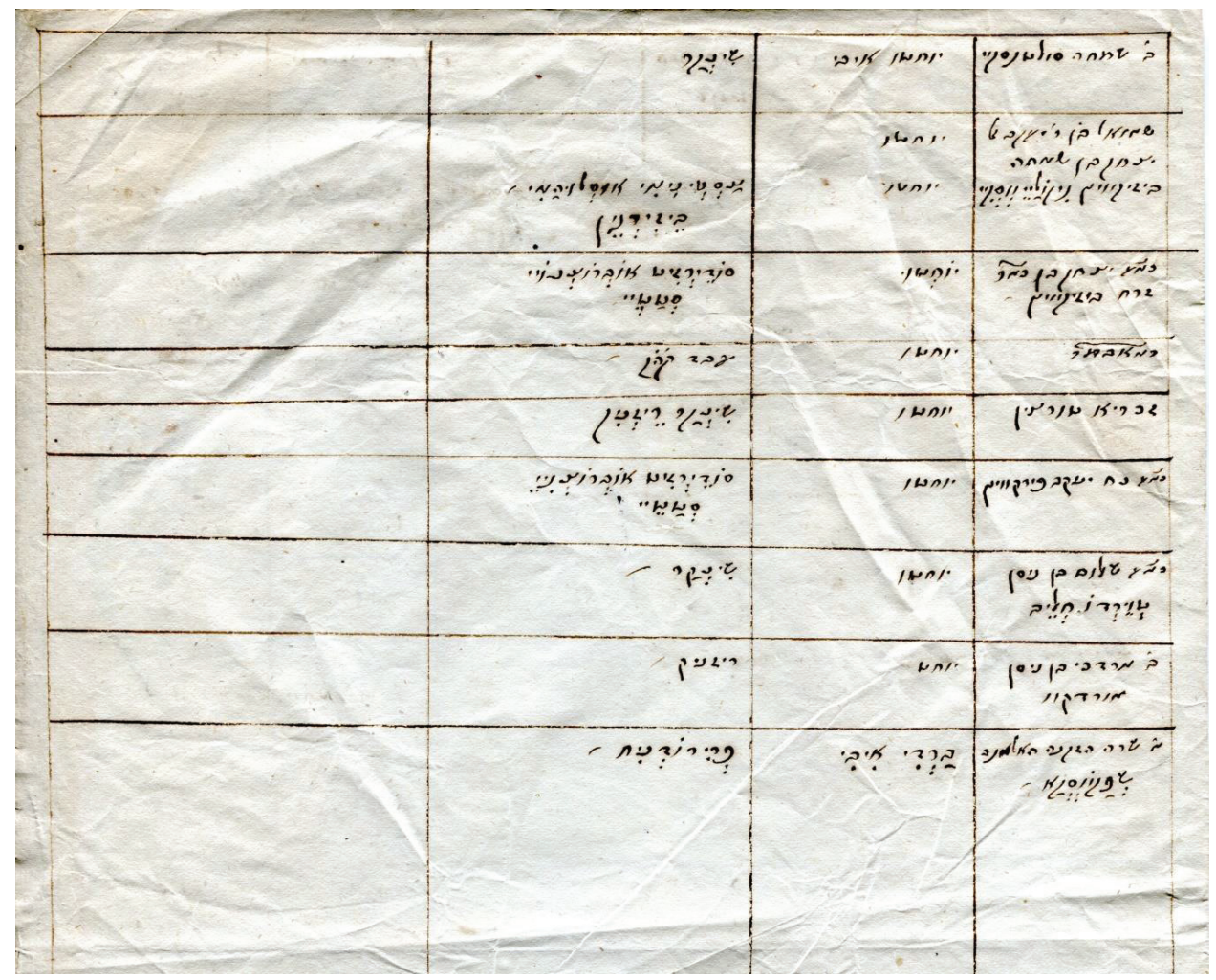

Folio 2 recto 